\title{
Methods of Testing Small Fire Extinguishers
}

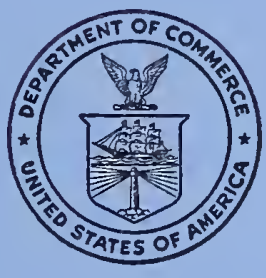

United States Department of Commerce

National Bureau of Standards

Building Materials and Structures Report 150 


\section{BUILDING MATERIALS AND STRUCTURES REPORTS}

On request, the Superintendent of Documents, U. S. Government Printing Office, Washington 25, D. C., will place your name on a special mailing list to receive notices of new reports in this series as soon as they are issued. There will be no charge for receiving such notices.

If 100 copies or more of any report are ordered at one time, a discount of 25 percent is allowed. Send all orders and remittances to the Superintendent of Documents, $U$. S. Government Printing Office, Washington $25, D$. C.

The following publications in this series are available by purchase from the Superintendent of Documents at the prices indicated:

BMS1 Research on Building Materials and Structures for Use in Low-Cost Housing - . . - .-

BMS2

BMS3

BMS4

BMS5

BMS6

BMS7

BMS8

BMS9

BMS10

Methods of Determining the Structural Properties of Low-Cost House Constructions -

Suitability of Fiber Insulating Lath as a Plaster Base..........

Aecelerated Aging of Fiber Building Boards

Structural Properties of Six Masonry Wall Constructions

Survey of Roofing Materials in the Southeastern States...

Water Permeability of Masonry Walls

Methods of Investigation of Surface Treatment for Corrosion Protection of Steel-.Constructions for Walls, Partitions, Floors, and Roofs

Structural Properties of One of the "Keystone Beam Steel Floor" Constructions Sponsored by the H. H. Robertson Co

BMS11 Struetural Properties of the Curren Fabrihome Corporation's "Fabrihome" Constructions for Walls and Partitions.

BMS12 Structural Properties of "Steelox" Constructions for Walls, Partitions, Floors, and Roofs, Sponsored by Steel Buildings, Inc

BMS13

BMS14

BMS15

Properties of Some Fiber Building Boards of Current Manufacture...

Indentation and Recovery of Low-Cost Floor Coverings

Structural Properties of "Wheeling Long-Span Steel Floor" Construction Sponsored

BMS16 Structural Properties of a "Tilecrete" Floor Construction Sponsored by Tilecrete Floors, Inc _

BMS17

BMS18

Sound Insulation of Wall and Floor Constructions

Structural Properties of "Pre-fab" Construction for Walls, Partitions, and Floors Sponsored by Harnischfeger Corporation.

BMS19

BMS20

BMS21

Preparation and Revision of Building Codes by Connecticut Pre-Cast Buildings Corporation

Structural Properties of a Concrete-Block Cavity-Wall Construction Sponsored by the National Concrete Masonry Association

BMS22 Structural Properties of "Dun-Ti-Stone" Wall Construction Sponsored by the W. E. Dunn Manufacturing Co

BMS23

BMS24

Structural Properties of a Brick Cavity-Wall Construction Sponsored by the Brick Manufacturers Association of New York, Inc Structural Properties of a Reinforced-Brick Wall Construction and a Brick-Tile CavityWall Construction Sponsored by the Structural Clay Products Institute

BMS25 Structural Properties of Conventional Wood-Frame Constructions for Walls, Partitions, Floors, and Roofs
Structural Properties of "Nelson Pre-Cast Concrete Foundation" Wall Construction Sponsored by the Nelson Cement Stone Co., Inc
Structural Properties of "Bender Steel Home" Wall Construction Sponsored by the

Bender Body Co ${ }_{\text {B }}$ Bow Prevention in Over-Rim Water Supplies

Survey of Roofing Materials in the Northeastern States
Structural Properties of a Wood-Frame Wall Construction Sponsored by the Douglas Fir Plywood Association

BMS28

BMS30

BMS31 Structural Properties of "Insulite" Wall and "Insulite" Partition Constructions Sponsored by The Insulite Co

BMS32 Structural Properties of Two Brick-Concrete-Block Wall Constructions and a ConcreteBlock Wall Construction Sponsored by the National Concrete Masonry Association

BMS33

BMS34

BMS35

BMS36

Plastic Calking Materials

Performance Test of Floor Coverings for Use in Low-Cost Housing: Part

Stability of Sheathing Papers as Determined by Accelerated Aging

Structural Properties of Wood-Frame Wall, Partition, Floor, and Roof Constructions Witl "Red Stripe" Lath Sponsored by the Weston Paper and Manufacturing Co. -

$*$

*

* Out of print.

† Superseded by BMS144.

+ Superseded by BMSil6. 


\section{Methods of Testing Small Fire Extinguishers}

H. Shoub, T. G. Lee, and J. M. Cameron

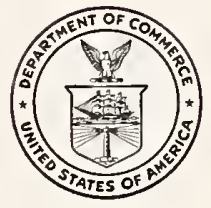

\section{Building Materials and Structures Report 150} Issued June 14, 1957 


\section{Contents}

1. Introduction _.......... 1

2. Description of test extinguishers and agents

3. Description of test methods

4. Results

5. Discussion of results

6. Conclusions 


\title{
Methods of Testing Small Fire Extinguishers
}

\author{
H. Shoub, T. G. Lee, and J. M. Cameron
}

\begin{abstract}
A study has been made of methods of testing small hand-portable fire extinguishers considered suitable for application to flammable liquids. The sturly was performed by eraluating the effectiveness of the extinguishers, in which 5 different extinguishing agents were used on 10 types of fires, selected either because they had been used in standard extinguisher tests or simulated other possible conditions of hazard. An analysis was made of the relative merit of the fires for extinguisher testing, the effect of ambient variables on the tests, and the value of the several extinguisher types for use on the fires.
\end{abstract}

\section{Introduction}

Although several types of small hand-portable fire extinguishers have been available for combatting fires of flammable liquids, the relative efficiency of these devices has been little understood. The continuing work of the National Bureau of Standards has led inevitably to the conclusion that wide variations in performance were obtained with these derices. To determine a means for' measuring the extent of these variations, a program of tests was undertaken under the sponsorship of the U.S. Coast Guard. Thile the primary purpose was to establish some standard of suitability of extinguishers for use on small motorcraft, it is considered that the work was of sufficiently broad aspect to allow extension of the applicability of the findings to many types of small flammable liquid fires.

In planning the tests, the program was enrisaged in several parts. A group of fire extinguishers was selected to apply the extinguishing agents used in the study. Each device was representative of its type and class, and individually without defects that could impair its performance. A series of suitable fires were selected or devised. These included sereral types of test fires used by commercial testing agencies and the National Bureau of Standards. Additional types, making for a total of 10, were based on preliminary designs of the Merchant Marine Technical and Testing and Derelopment Dirisions of the Coast Guard. Finally, the effect of ambient variables on the tests was noted. Statistical methods were used in planning the tests and in analyzing the large body of data resulting from the program.

\section{Description of Test Extinguishers and Agents}

Fifteen extinguishers, all readily obtainable commercial makes, were chosen for the purposes of these tests. Each carried the Under'writer's' Laboratories, Inc. B-2 rating. Among these were devices using all common types of extinguishing agents suitable for flammable-liquid fires, and further varied in capacity, and in rate, duration. range, and continuity of discharge. At the end of the program no wear or damage to the devices sufficient to affect their operating efficiency in any way was found. The extinguishers used are listed in table 1.

The extinguishers used may be classified into 4 groups according to the type of agent employed: vaporizing liquid, carbon dioxide, dry chemical, and foam. Of the 8 devices using raporizing liquid. 7 were charged with carbon tetrachloride extinguisher fluid and 1 with chlorobromomethane. Of these, 4 were hand pumps; the remainder depended on gas pressure stored in the charge chamber to give the necessary expelling force. The carbon tetrachloride was supplied under the requirements of the Federal specification for this material. The single chlorobromomethane device was charged with fluid stated to comply with U. S. Air Force requirements. Two of the hand-pump extinguishers had a slightly intermittent action, and were the only ones in which the discharge rate was under the control of the operator. Because of differences in the mechanism, two of each size of hand-pump carbon tetrachloride extinguishers were included.

The three carbon dioxide type extinguishers each had different capacities: $21 / 2,5$, and $10 \mathrm{lb}$. They were charged from standard $\mathrm{CO}_{2}$ cylinders. The gas pressure in a fully charged device of any size is about $850 \mathrm{lb} / \mathrm{in}^{2}$ at $70^{\circ} \mathrm{F}$. Approximately 75 percent by weight of the discharge is effective for fire extinguishment.

Two of the three extinguishers in the drychemical group were of the stored-pressure trop. and consisted of 4 - and 5 -lb devices. The third had its expelling gas in the form of a cartridge. and was of $4-1 \mathrm{~b}$ capacity. Ilthough all the Alry chemicals consisted of finely ground bicirbonate of soda treated with a water repellent. only material mamufactmed for the particulal extinguisher was nsed in each case.

A single extinguisher was of the foan type. It had $1 \frac{1}{4}$-gal capacity, and was the only derice of the 15 tested that was lated for mse on ordinaty combustible materials, as well as on flammable liquids. Also, it was not suited tor electrical tires. for which the other 14 extinguishers of the pro- 
Table 1. Extinguishers used in the fire tests

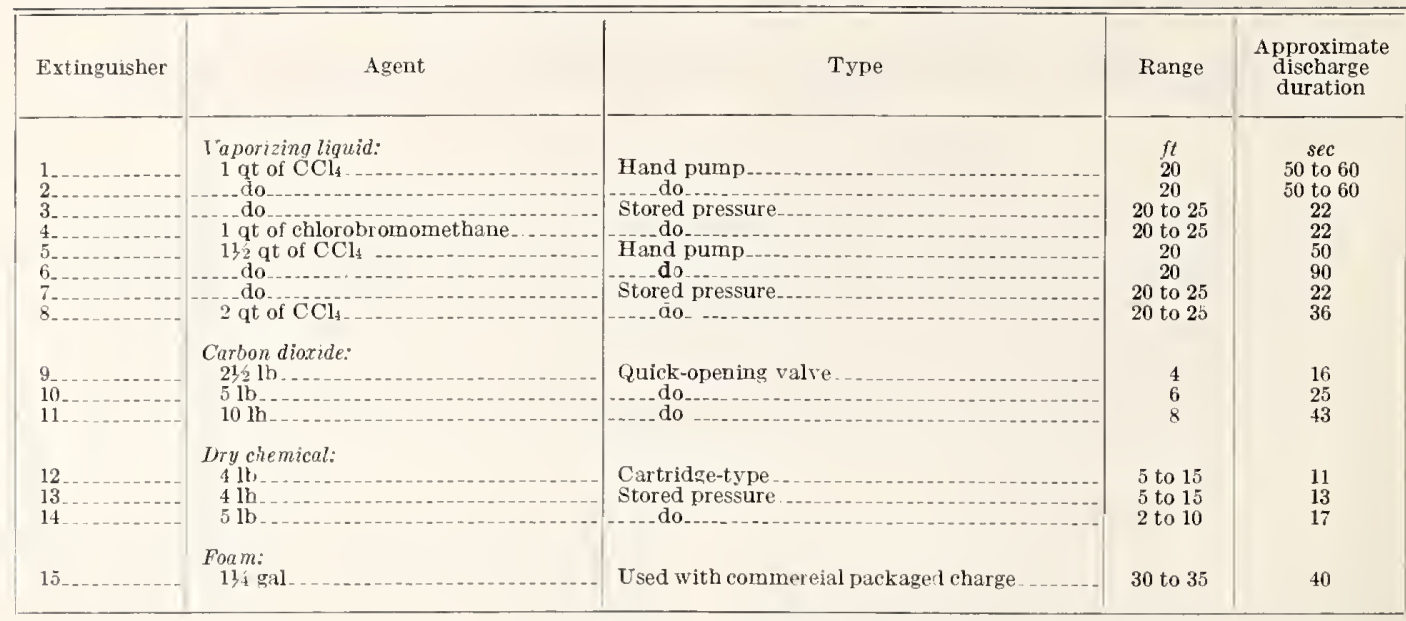

gram were acceptable. The discharge, once initiated, could not be terminated before total exhaustion. Commercial foam materials, which had been previously found to give consistently good performance, were used for the charge.

Manufacturer's' charging instructions were followed closely. In most cases charges were established on a weight basis, with a tolerance of \pm 0.05 lb. However, to provide a space of constant rolune for the gas in stored pressure vaporizing liquid and dry chemical extinguishers, the charge weight in these devices was regulated to $0.01 \mathrm{lb}$. In order to minimize the intake of moisture into stored pressure extinguishers, which might adversely affect the charge in dry chemical devices or cause deterioration of the working parts of vaporizing liquid models, oil-pumped nitrogen was used as the expelling gas.

Discharge rate curves, determined empirically for extinguishers at approximately $70^{\circ} \mathrm{F}$, are shown in figure 1. Rates for hand-pump carbon tetrachloride extinguishers were based on average performance, using a pumping rate of approximately one full cycle per second.

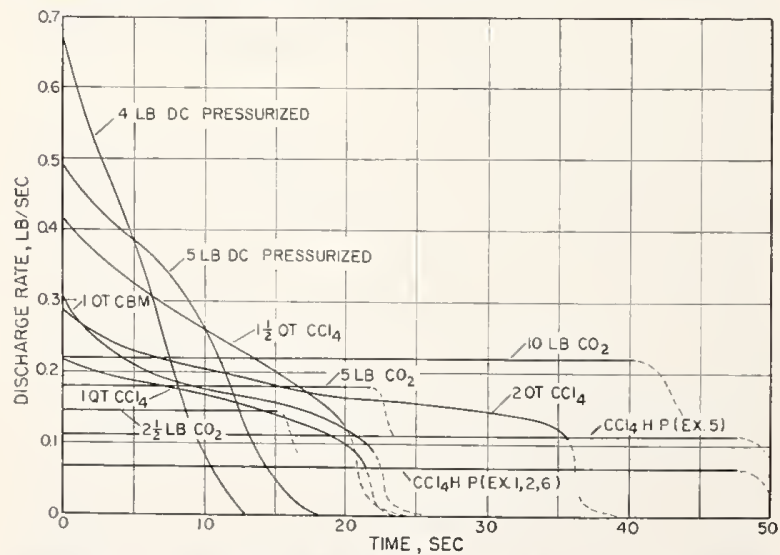

Figure 1. Approximate discharge rates of test extin. guishers.

\section{Description of Test Methods}

The three types of fires that have served as standard tests of small extinguishers for flammable liquids are the 4 -ft-square spill area, a cotton-waste fire, and a nominal 2 -ft-diameter tub. Four types were representative of fires in partially enclosed spaces, with or without an obstacle to free dispersal of the extinguishing agent. The enclosed space was simulated by a metal compartment in which changes in the opening could be effected by removal in whole or part of the end plates and top. The design of three of these types of fires was such that the fuel consumption rates were maintained at approximately the same level. The components of the compartment, as well as the pan used both alone and as the fuel container in the enclosed space, are shown in figure 2. The construction of the parts is shown in figure 3 . In addition, three other types of possible hazard were simulated. These included an open, shallow pan, a leaking container, and a spill flowing over a wide vertical surface.

As the extinguishers were intended primarily for flammable-liquid fires, the structures used in the several fire configurations were of noncombustible materials, although in certain tests a measured amount of an ordinary combustible, wood,

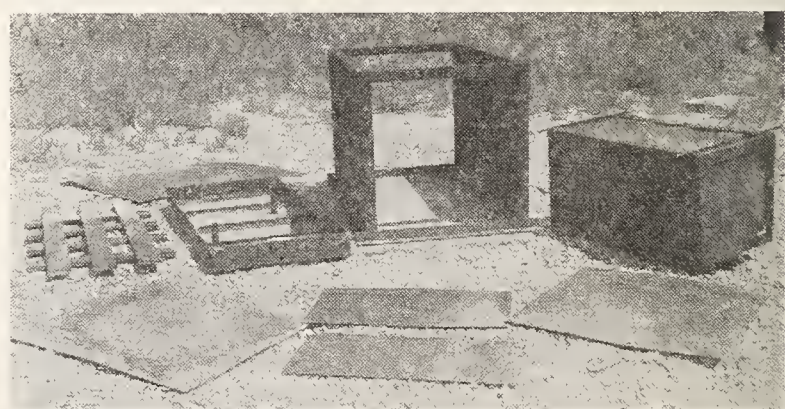

FIGURE 2. Compartment components, pan, and wood grating. 

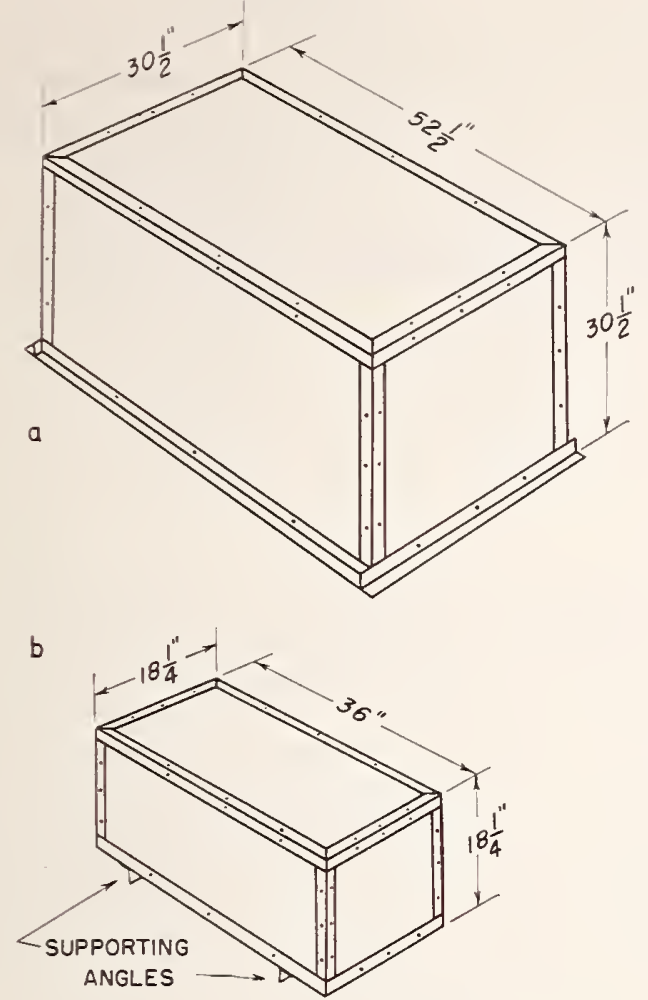

FIGURE 3. Compartment and obstacle.

Both units made from 2-in. by 2-in. by 1/8-in. angle and 14 gage steel plate fastened with $1 / 4-$ in. bolts.

a, Compartment made with bottom open, long sides corered, top and end plates remorable: b, obstacle covered on all sides.

was introduced as a means of determining the effectiveness of the extinguishers on mixed fires. The fuel used in all but one of the tests was a commercial mixture of heptanes having a narrow distillation range at approximately $200^{\circ} \mathrm{F}$. This fuel, rather than gasoline, was used in order to create reproducible conditions of fuel consumption throughout the program, as well as to provide fair burning equilibrium during the course of a single trial. The distillation curves for the test fuel and the average of a number of gasolines are shown in figure $4 .^{1}$ The properties of gasoline are known to fluctuate seasonally, and vary with the producer and point of origin. Gasoline, also, because of its wide volatile range, exhibits marked differences in characteristics during the burning of a specimen, with rapid consumption of the more volatile portion and ending in progressively slower consumption of heavy fractions. Radiant-energy measurements for several gasolines and the heptane mixture were approxi-

I O. C. Blade, Bureau of Mines, Dept. Interior, National Motor Gasoline Survey of Summer 1954, Report of Investigation 5111 (January 1955).

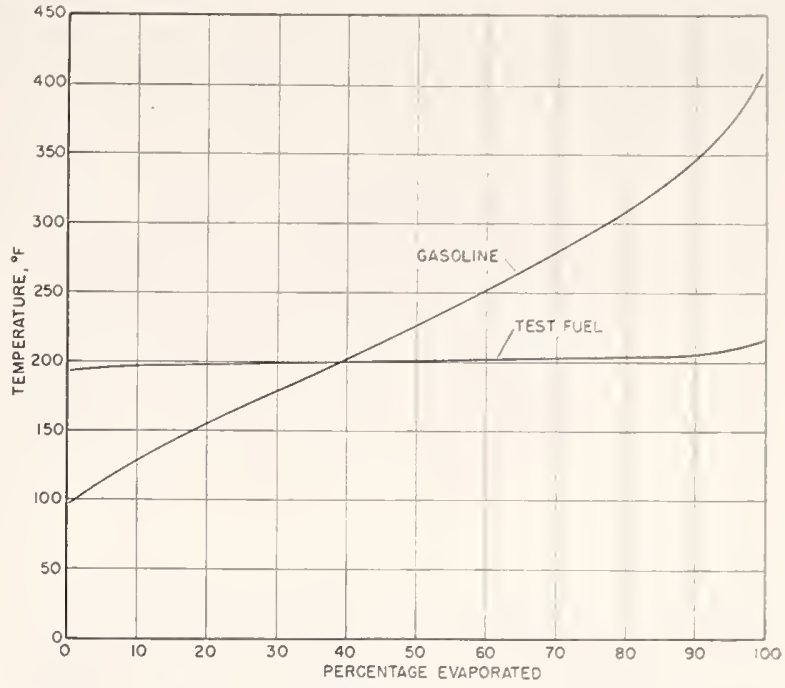

HIGURE 4. Distillation curces of gasolines and test fuel

Gasoline curve represents average of 350 regulars tested midAtlantic States, summer, 1954.

mately the same. In duplicate tests, made with the two fuel types, no appreciable differences were noted in extinguisher performance that could be attributed to the type of fuel used. To introduce the effect of another type of fuel, an exception was made in the case of the rertically flowing spill fire, in which alcohol was used.

Fuel-consumption rates were determined from time to time cluring the program to check the consistency of the tests. However, it was noted that changes in ambient conclitions, which ranged from calm to moderately high wind and from $32^{\circ}$ to $85^{\circ}$ $\mathrm{F}$, had little significant effect on the fuel consumption.

Each of the test fires is described, with pertinent data, in table 2. The pan used in fires VI through $\mathrm{X}$ had dimensions of 4 by $2+$ by 48 in. The fuel in the pan, as well as in the 2 -ft tub, was poured over approximately $1 \mathrm{in}$. of water. The four types of wood gratings used on the pan to control the burning rate, as well as to add a fuel complication, are shown in figure 5. The axangement of openings in the compartment for fire types VII to $\mathrm{X}$ are shown in figure 6 .

In the program, a test of each of the $15 \mathrm{ex}$ tinguishers on the 10 types of fires. defined hexe as a series, was repeated 5 times to provide sutficient data for a significant statistienl analysis of the results. The experiment was progrimed so that the intelcomparison among extmemishes would not be aflected by differences in weathex conditions or other factors changing with time. Generally, it was possible to comelnet tests of all 15 extinguishers on a single type of time in a day. The schedule was so allanged that wath day sopere- 


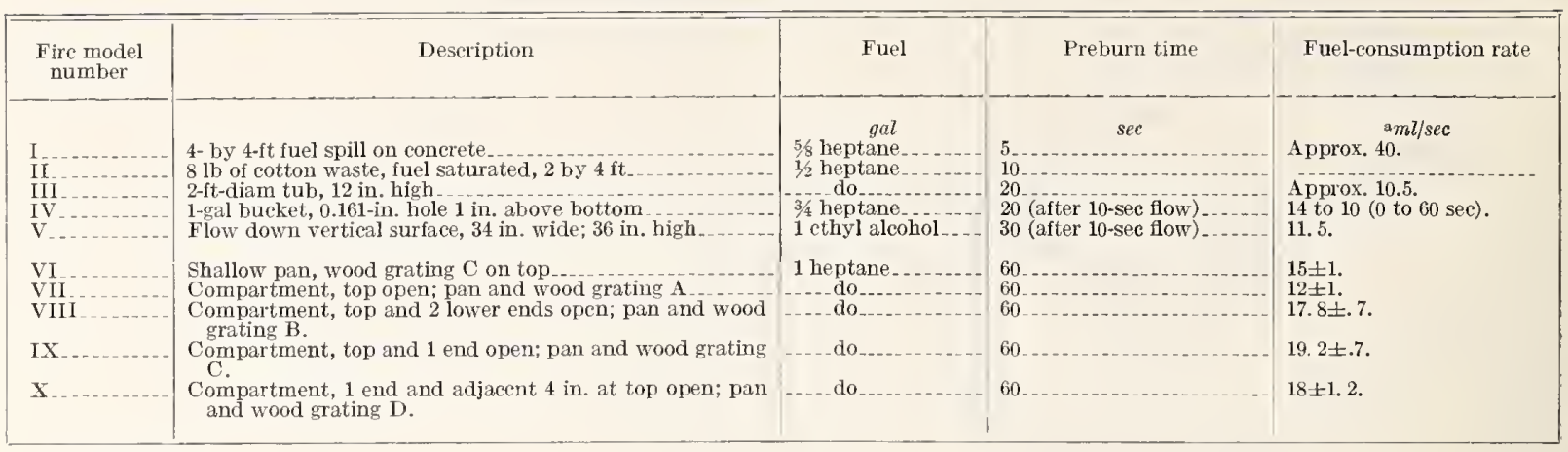

a $1 \mathrm{ml}=0.000264 \mathrm{gal}$.

ation was divided into 5 time periods of 3 extinguishers each. In the course of the program, all 15 extinguishers were used in each of the time periods on each fire.

While comparatively experienced operators were used, the results were nevertheless influenced by the operator's' techniques and to some extent by experience acquired in the tests. In an effort to simulate actual conditions as nearly as possible, no special protective equipment was provided the operators. In attacking fires, the approach was as close as that allowed by the intensity of the radiant heat, or as near as that required for the apparent optimum use of the extinguishers.

The data taken during each test included various observations of weather conditions, such as temperature, wind velocity and direction, barometric pressure, and humidity. Temperatures of the fuel and the extinguishers, the latter maintained at approximately $70^{\circ} \mathrm{F}$, were noted. The method of attack and the amount of extinguishing agent expended were also recorded.



A



SECTIONA-A

Figure 5. Wood gratings.

Gratings are constructed of Ponderosa pine, No. 2. common, nominal 1-in. by 4 -in. mill lumber (dressed dimensions $25 / 32$ in. by $3 \frac{5}{8}$ in.).
An attempt was made to take into consideration essential information that would be lost if rating were simply on the basis of percentage of success or failure. This was done by assigning a score to each trial. An arbitrary rating system was established, based on six levels of success, ranging from +3 to -3 , with the plus scores assigned to cases in which the fire was extinguished, highest number for easiest accomplishment, and minus numbers for failures, -3 representing the case of least effectiveness. Generally, the plus ratings were based on the unexpended amount of extinguishing agent. Because in cases of failure the charge was completely spent, minus ratings ranging from -1 , almost extinguished, to -3 , no apparent attenuation, were assigned on the basis of the operators' judgment.

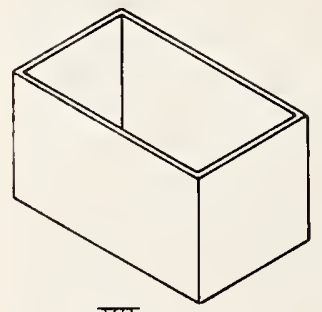

VIII

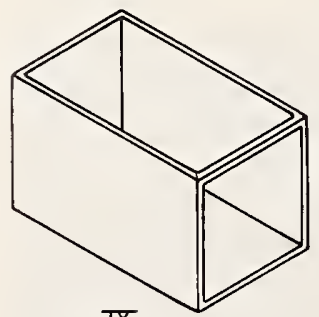

IX

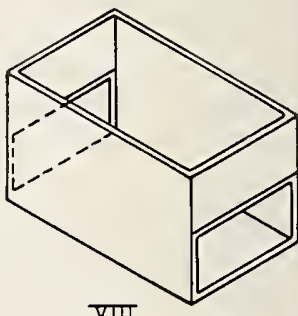

VIII

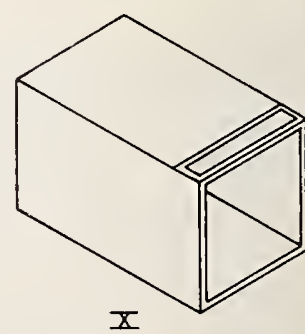

FIGURE 6. Arrangement of compartment openings for extinguisher tests.

Fuel pan, wood grating, and obstacle not shown. 


\section{Results}

The performance ratings of the 5 trials of each of the 15 extinguishers on the 10 types of fires, 750 tests in all, are shown graphically in figure 7. Considering the 150 group results solely on the basis of success or failure in extinguishment, 94 shorred complete agreement in the 5 runs, 30 had 1 disagreement, with the remaining 26 marked by a 3 -and-2 split.

In the data for the 4- by 4-ft. spill fire (No. I), a dotted-circle designation indicates those cases in which extinguishment was accomplished after the fire area was considerably reduced from its original size. It was observed that this occurred in about $30 \mathrm{sec}$. Thus devices requiring more than this time to effect extinguishment are not comparable to those actually successful against the fullsized fire. For statistical purposes in ranking extinguishers, the dotted-circle designation was assigned a rating of +1 .

The saturated cotton-waste fire (No. II) was characterized by nonuniformity of fire source during the extinguishment period as all or most of the liquid fuel was exhausted after about $60 \mathrm{sec}$ of burning. This left a slow-burning-cotton fire not representative of a flammable-liquid hazard.
Although in many cases there was momentary extinction of the flames by the time the extinguisher charge was exhausted, reignition usually occurrerl in the large body of glowing and smoldering material. In assigning performance ratings on this fire, results were considered sucressful if reignition did not occur within 弓, min.

Table 3 gives the sums of the scores obtained on each of the 5 separate trials on the different test fires. A tabulation of the number of times each extinguisher succeeded in putting out the 10 fires is given in table 4 . In table 5 the data show the differences between series. Each entry represents the number of successes of a given extinguisher summed over all fires in a series. A significant effect here is the fact that series 1 shows fewer successes than the remaining 4 series. The order of listing in tables 4 and 5 is roughly that of relative effectiveness achieved with the devices, but is also determined by grouping according to extinguisher type. Using the same arrangement, the relative rankings of the performance of the 1 \% devices, based on several methods of comparison, are presented in table 6. All methods of performance measurement give essentially the same rankings. Reasons for the omission of fire To. II in tables 4 and 6 are given in the following discussion.

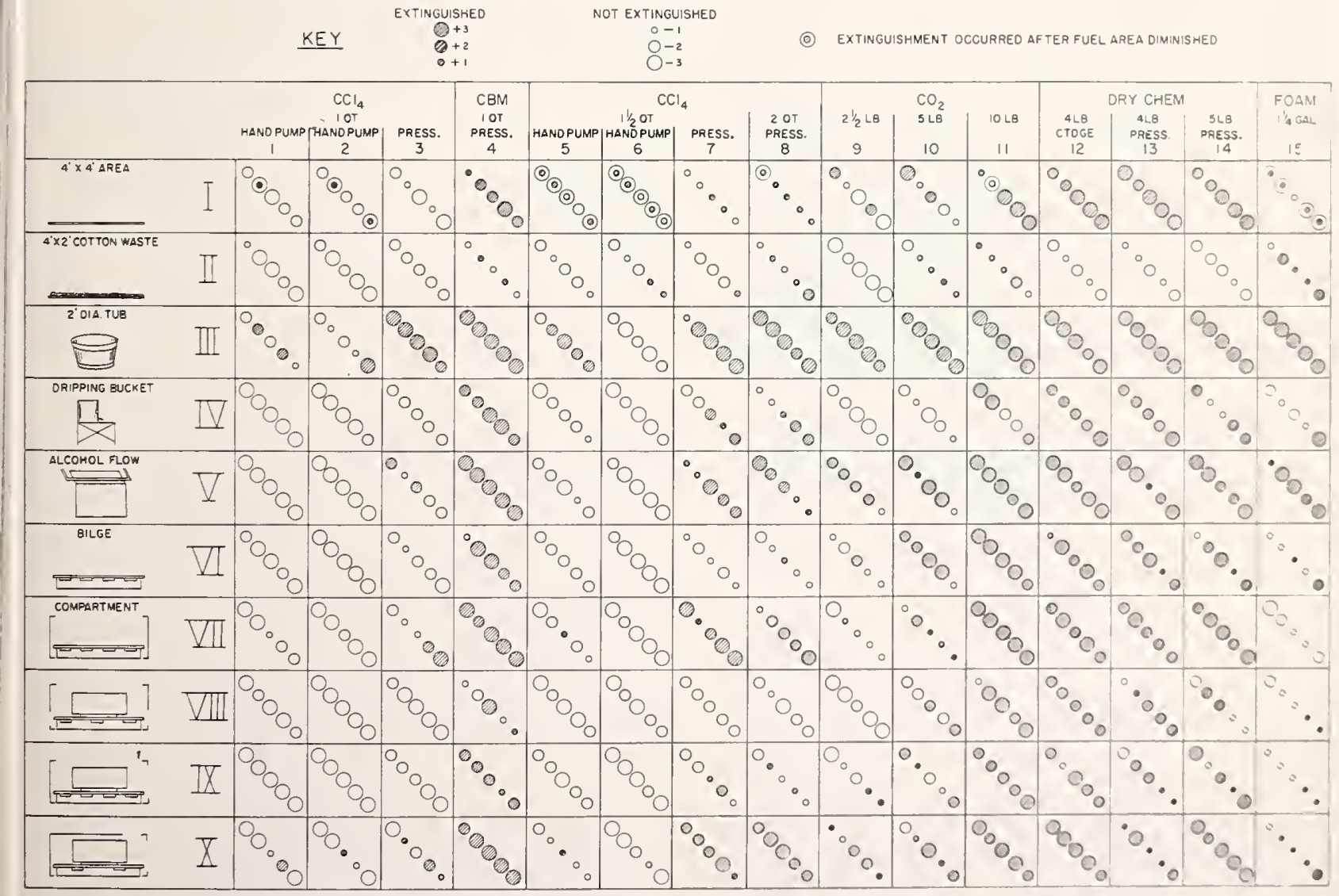

FIgURE 7. Performanee obtained with extinguishers on test fires. 
Table 3. Sum of scores obtained with the 15 extinguishers on each of the 10 fire types (sum of 5 runs)

\begin{tabular}{|c|c|c|c|c|c|c|c|c|c|c|}
\hline \multirow{2}{*}{ Extinguisher } & \multicolumn{10}{|c|}{ FIRE MODEL NYMMER } \\
\hline & I & II & III & IV & $\mathrm{V}$ & VI & VII & VIII & $\mathrm{IX}$ & $\mathrm{x}$ \\
\hline $\begin{array}{l}1 . \ldots- \\
2-\ldots \\
3-\ldots \\
4-\ldots \\
5 \ldots\end{array}$ & $\begin{array}{r}-8 \\
-4 \\
-10 \\
10 \\
2\end{array}$ & $\begin{array}{r}-12 \\
-13 \\
-10 \\
-1 \\
-8\end{array}$ & $\begin{array}{r}-1 \\
-3 \\
14 \\
15 \\
7\end{array}$ & $\begin{array}{r}-15 \\
-14 \\
-10 \\
12 \\
-10\end{array}$ & $\begin{array}{r}-15 \\
-15 \\
-1 \\
15 \\
-10\end{array}$ & $\begin{array}{r}-13 \\
-15 \\
-10 \\
11 \\
-10\end{array}$ & $\begin{array}{r}-11 \\
-14 \\
1 \\
14 \\
-7\end{array}$ & $\begin{array}{r}-13 \\
-15 \\
-14 \\
0 \\
-13\end{array}$ & $\begin{array}{r}-15 \\
-15 \\
-12 \\
9 \\
-11\end{array}$ & $\begin{array}{r}-8 \\
-9 \\
-1 \\
14 \\
-4\end{array}$ \\
\hline $\begin{array}{l}6 \\
7 \\
8 \\
9 \\
10 \\
\end{array}$ & $\begin{array}{r}5 \\
-1 \\
5 \\
-3 \\
1\end{array}$ & $\begin{array}{r}-3 \\
-6 \\
2 \\
-14 \\
2\end{array}$ & $\begin{array}{r}-12 \\
13 \\
14 \\
13 \\
14\end{array}$ & $\begin{array}{r}-13 \\
1 \\
3 \\
-12 \\
-9\end{array}$ & $\begin{array}{r}-14 \\
9 \\
9 \\
7 \\
9\end{array}$ & $\begin{array}{r}-14 \\
-7 \\
-4 \\
-3 \\
9\end{array}$ & $\begin{array}{r}-14 \\
12 \\
8 \\
-3 \\
4\end{array}$ & $\begin{array}{r}-12 \\
-10 \\
-10 \\
-14 \\
2\end{array}$ & $\begin{array}{r}-14 \\
-2 \\
-2 \\
-4 \\
2\end{array}$ & $\begin{array}{r}-12 \\
10 \\
12 \\
5 \\
5\end{array}$ \\
\hline $\begin{array}{l}11 \\
12 \\
13 \\
14 \\
15\end{array}$ & $\begin{array}{r}11 \\
13 \\
14 \\
13 \\
3\end{array}$ & $\begin{array}{r}4 \\
-8 \\
-7 \\
-9 \\
5\end{array}$ & $\begin{array}{l}15 \\
14 \\
15 \\
15 \\
15\end{array}$ & $\begin{array}{r}4 \\
11 \\
11 \\
4 \\
-3\end{array}$ & $\begin{array}{l}14 \\
14 \\
12 \\
13 \\
12\end{array}$ & $\begin{array}{r}14 \\
11 \\
10 \\
7 \\
0\end{array}$ & $\begin{array}{r}15 \\
12 \\
11 \\
13 \\
-9\end{array}$ & $\begin{array}{r}10 \\
10 \\
6 \\
0 \\
-2\end{array}$ & $\begin{array}{r}11 \\
8 \\
4 \\
8 \\
-1\end{array}$ & $\begin{array}{r}13 \\
14 \\
8 \\
14 \\
4\end{array}$ \\
\hline Totais_... & +51 & -78 & +148 & -40 & +59 & -14 & +32 & -79 & -34 & +65 \\
\hline
\end{tabular}

TABLE 4. Number of successes with each extinguisher in five trials on each fire type

\begin{tabular}{|c|c|c|c|c|c|c|c|c|c|c|c|c|c|}
\hline \multicolumn{2}{|r|}{ Extinguisher } & \multicolumn{10}{|c|}{ FIRE MODEL NUMBER } & \multirow{2}{*}{$\begin{array}{c}\text { Total } \\
\text { number } \\
\text { in } 50 \\
\text { trials }\end{array}$} & \multirow{2}{*}{$\begin{array}{l}\text { Total } \\
\text { number } \\
\text { in } 45 \\
\text { triais }\end{array}$} \\
\hline No. & Agent & I & II & III & IV & V & VI & VII & VIII & IX & $\mathrm{X}$ & & \\
\hline 2. & $\mathrm{CCl}_{4-\ldots}$ & 2 & 0 & 1 & 0 & $n$ & 0 & 0 & 0 & 0 & 1 & 4 & 4 \\
\hline 1. & $\mathrm{CCl}_{1} \ldots$ & 1 & 0 & 2 & 0 & 0 & 0 & 0 & 0 & 0 & 1 & 4 & 4 \\
\hline 6 - - & $\mathrm{CCl}_{4} \ldots$ & 5 & 2 & 0 & 0 & 0 & 0 & 0 & 0 & 0 & 0 & 7 & 5 \\
\hline 5 & $\mathrm{CCl}_{4}$ & 4 & 0 & 4 & 0 & 0 & 0 & ] & 0 & 0 & 1 & 10 & 10 \\
\hline $3 \ldots$ & $\mathrm{CCl} \mathrm{Cl}_{4}$ & 0 & 0 & 5 & 0 & 2 & 0 & 2 & 0 & 0 & 3 & 12 & 12 \\
\hline $\begin{array}{l}7 \ldots \\
8 \ldots\end{array}$ & $\begin{array}{l}\mathrm{CCl}_{4} \\
\mathrm{CCl}\end{array}$ & $\begin{array}{l}2 \\
5\end{array}$ & $\begin{array}{l}1 \\
3\end{array}$ & $\begin{array}{l}5 \\
5\end{array}$ & $\begin{array}{l}3 \\
3\end{array}$ & $\begin{array}{l}5 \\
5\end{array}$ & $\begin{array}{l}0 \\
1\end{array}$ & $\begin{array}{l}5 \\
4\end{array}$ & $\begin{array}{l}0 \\
0\end{array}$ & $\begin{array}{l}2 \\
3\end{array}$ & $\begin{array}{l}5 \\
4\end{array}$ & $\begin{array}{l}28 \\
33\end{array}$ & $\begin{array}{l}27 \\
30\end{array}$ \\
\hline 15 & Foam & 4 & 4 & 5 & 1 & 5 & 2 & 0 & 2 & 2 & 4 & 29 & 25 \\
\hline 9. & $\mathrm{CO}_{2}$ & 2 & 0 & 5 & 0 & 4 & 1 & 2 & 0 & 2 & 4 & 20 & 20 \\
\hline $10 \ldots$ & $\mathrm{CO}_{2} \ldots$ & 2 & 4 & 5 & 0 & 4 & 4 & 4 & 2 & 2 & 5 & 32 & 28 \\
\hline $11 \ldots$ & $\mathrm{CO}_{2} \ldots \ldots$ & 5 & 4 & 5 & 3 & 5 & $\overline{5}$ & 5 & 4 & 5 & 5 & 46 & 42 \\
\hline 14. & Dry chemical .... & 5 & 0 & 5 & 3 & 5 & 4 & 5 & 2 & 4 & 5 & 38 & 38 \\
\hline $13 \ldots$ & 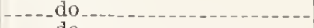 & 5 & 0 & 5 & 5 & 5 & 5 & 5 & 4 & 4 & 5 & 43 & 43 \\
\hline $12 \ldots$ & -..... do & 5 & 0 & 5 & 5 & 5 & 5 & 5 & 5 & 4 & 5 & 44 & 44 \\
\hline \multirow[t]{2}{*}{$4 \ldots \ldots$} & Chlorobromomethane.....-- & 5 & 2 & 5 & 5 & 5 & 5 & 5 & 2 & 5 & 5 & 44 & 42 \\
\hline & Totals - & 52 & 20 & 62 & 28 & 50 & 32 & 43 & 21 & 33 & 53 & 394 & 374 \\
\hline
\end{tabular}

a Omitting fire No. II.

TABLE 5. Total number of successes with each extinguisher on all 10 fire types in each of the 5 series

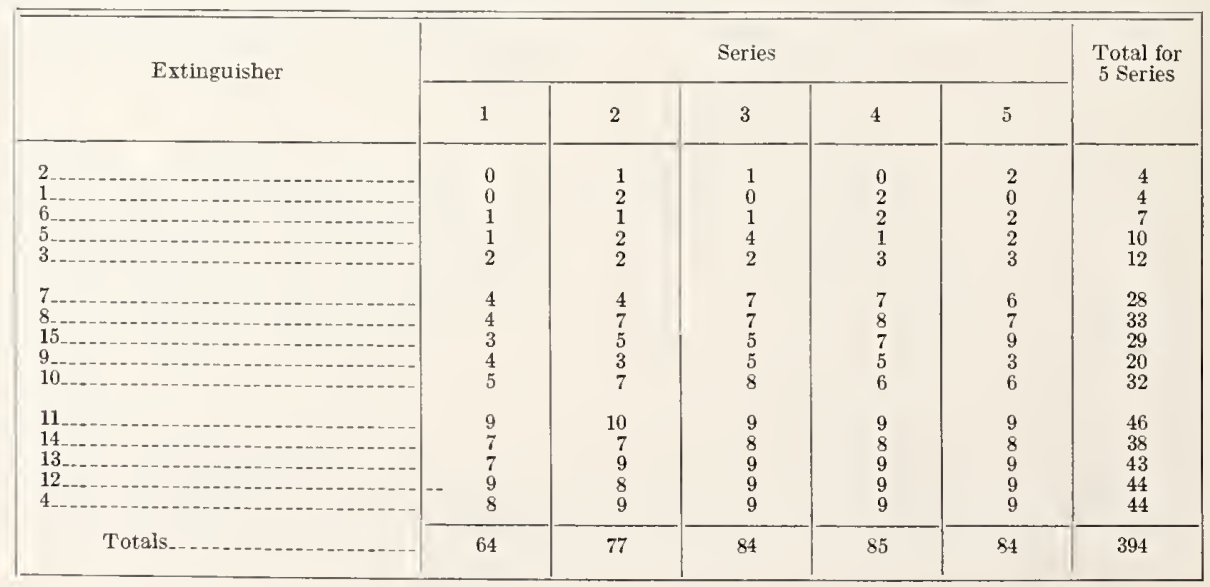




\begin{tabular}{|c|c|c|c|c|c|c|c|c|c|c|}
\hline \multirow{2}{*}{ Estinguisher } & \multirow{2}{*}{ Agent and amount } & \multirow{2}{*}{ Type } & \multirow{2}{*}{$\begin{array}{c}\text { A } \\
\text { Percent- } \\
\text { age of } \\
\text { success }\end{array}$} & \multirow{2}{*}{$\begin{array}{c}\text { B } \\
\text { Pcrcent- } \\
\text { age of } \\
\text { success, } \\
\text { omitting } \\
\text { fire } 11\end{array}$} & \multirow{2}{*}{$\begin{array}{c}\text { C } \\
\begin{array}{c}\text { A verage } \\
\text { scores }\end{array}\end{array}$} & \multirow{2}{*}{$\begin{array}{c}\text { D } \\
\text { Average } \\
\text { scores, } \\
\text { omitting } \\
\text { fire } 11\end{array}$} & \multicolumn{4}{|c|}{ Panking according to- } \\
\hline & & & & & & & $A$ & B & C & I) \\
\hline $\begin{array}{l}2-. \\
1-. \\
6-. \\
5-.\end{array}$ & $\begin{array}{l}\mathrm{CCl}_{4}, 1 \text { qt } \ldots . . \\
\mathrm{CCl}_{1}, 1 \text { qt } \ldots \\
\mathrm{CCl}_{4}, 132 \mathrm{qt} . . \\
\mathrm{CCl}_{4}, 132 \mathrm{qt} . .\end{array}$ & $\begin{array}{l}\text { Hand pump...... } \\
\text { do } \\
\text { do }\end{array}$ & $\begin{array}{r}8 \\
8 \\
14 \\
20\end{array}$ & $\begin{array}{r}9 \\
9 \\
11 \\
22\end{array}$ & $\begin{array}{l}-2.3 \\
-2.2 \\
-2.1 \\
-1.3\end{array}$ & $\begin{array}{l}-2.3 \\
-2.2 \\
-2.2 \\
-1.2\end{array}$ & $\begin{array}{l}1.5 \\
1.5 \\
3 \\
1\end{array}$ & $\begin{array}{l}1.5 \\
1.5 \\
3 \\
4\end{array}$ & $\begin{array}{l}1 \\
2 \\
3 \\
4\end{array}$ & $\begin{array}{l}1 \\
3 \\
2 \\
4\end{array}$ \\
\hline $\begin{array}{l}3 . . . \\
7 .- \\
8 \ldots\end{array}$ & $\begin{array}{l}\mathrm{CCl}_{4,1}, 1 \mathrm{qt} \\
\mathrm{CCl}_{4}, 132 \mathrm{qt} \\
\mathrm{CC}_{4}, 2 \mathrm{qt}^{-}\end{array}$ & $\begin{array}{l}\text { Pressurized } \\
\text { do }\end{array}$ & $\begin{array}{l}24 \\
56 \\
66\end{array}$ & $\begin{array}{l}27 \\
60 \\
67\end{array}$ & $\begin{array}{r}-1.1 \\
0.4 \\
.7\end{array}$ & $\begin{array}{r}-1.0 \\
0.6 \\
.8\end{array}$ & $\begin{array}{r}\frac{5}{7} \\
10\end{array}$ & $\begin{array}{r}5 \\
8 \\
10 \\
10\end{array}$ & $\frac{5}{7}$ & $\begin{array}{r}5 \\
3 \\
10\end{array}$ \\
\hline 15 & Foam, $13+\mathrm{gal}$ & & 58 & 56 &. & .4 & $x$ & 7 & 8 & 7 \\
\hline $\begin{array}{l}9 \ldots-\ldots \\
10 \ldots \\
11 \ldots\end{array}$ & $\begin{array}{l}\mathrm{CO}_{2}, 23 \mathrm{j} \mathrm{lb} \ldots \ldots \\
\mathrm{CO}_{2}, 5 \mathrm{lb} \ldots \\
\mathrm{CO}_{2}, 10 \mathrm{lh}\end{array}$ &  & $\begin{array}{l}40 \\
64 \\
92\end{array}$ & $\begin{array}{l}41 \\
62 \\
93\end{array}$ & $\begin{array}{r}-.6 \\
2.7\end{array}$ & $\begin{array}{r}-.3 \\
2.5\end{array}$ & $\begin{array}{r}6 \\
9 \\
15\end{array}$ & $\begin{array}{c}6 \\
9 \\
9 \\
12.5\end{array}$ & $\begin{array}{r}6 \\
9 \\
15\end{array}$ & $\begin{array}{r}6 \\
9 \\
15\end{array}$ \\
\hline $\begin{array}{ll}14 \\
13 \\
12 \ldots\end{array}$ & $\begin{array}{l}\text { Dry chem., } 5 \mathrm{lb} \\
\text { Dry chem., }+\mathrm{lb} \\
\text { Dry chem., } 4 \mathrm{lb}\end{array}$ & $\begin{array}{l}\text { Stored pressure } \\
\text { Cartridge }\end{array}$ & $\begin{array}{l}76 \\
86 \\
88\end{array}$ & $\begin{array}{l}84 \\
96 \\
98\end{array}$ & $\begin{array}{l}1.6 \\
1.7 \\
2.0\end{array}$ & $\begin{array}{l}2.0 \\
2.0 \\
2.4\end{array}$ & $\begin{array}{l}11 \\
12 \\
13.5\end{array}$ & $\begin{array}{l}11 \\
14 \\
15\end{array}$ & $\begin{array}{l}11 \\
12 \\
13.5\end{array}$ & $\begin{array}{l}11.5 \\
11.5 \\
14\end{array}$ \\
\hline$t \ldots$ & Chlorobromomethane, $1 \mathrm{qt}_{\text {-. }}$ & Stored pressure.. & 88 & 93 & 2.0 & 2.2 & 13.5 & 12.5 & 13.5 & 13 \\
\hline
\end{tabular}

\section{Discussion of Results}

In considering the $9 \pm$ groups of consistent results where either extinguishment or failure occurred in all five trials of a derice on a particular fire, it may be assumed that the performance effectiveness of these extinguishers was such that variations in weather conditions and operator skill during any of the five runs was not sufficiently great as to change the outcome. The relative success or failure scorings within a group, howerer, were affected by these rariables.

Almost uniform success was possible in fighting fires with some extinguishers, whereas with some others there was equally consistent noneffectiveness. Also. the application of a certain extinguisher may have been a success against a minor fire on erei⿳亠口冋 trial. yet may have resulted in complete failure on a more serere type of hazard. The performance obtained with such a device on a fire of intermediate severity frequently resulted in neither all success nor all failure: success could depend on the right combination of environmental conditions and operator technique. If trials of an extinguisher showed a low percentage of success against a particular fire, these successes must have been achiered under a verv restrictive set of conditions. On the other hand, a device with which a high percentage of success was achieved could be said to be less sensitive to minor deviations from optimum operating conditions. In these tests, extinguishers used in trials characterized by a large number of nonuniform group results appear to be high-sensitivity-type devices.

The fire configuration seems to be of considerable importance in the effectiveness of extinguishment. The poorer performance obtained with carbon tetrachloride type extinguishers on fire VI than on V'II may be attributed to the lack of con- fining surfaces on the shallow-pan fire. This causes a reduction in the volume of decomposition products, which are best produced by vaporization against a hot surface. Also, there is no means of preventing the rapid dissipation of the rolatile gases that are formed. A specialized method of attack with carbon tetrachloride is illustrated by fire IV, in which fuel is fed through a small opening. By directing the stream of raporizing liquid directly at the source, the fuel could sometimes be diluted to a point at which it no longer sustained combustion.

In fire models VIII, IX and $\mathbf{X}$, where the fuel consumption rates throughout the program were approximately equal $(18.5 \pm 1.4 \mathrm{ml} / \mathrm{sec})$, confinement was apparently the primar'y factor attecting extinguisher performance. The test derices showed significantly greater effectiveness on in fire model such as No. X, in which the highly confined configuration tended to accumulate the agent to a concentration level necessary for extinguishment.

Accumulation of vaporizing agent. howerer. may not be the only explanation for this appant correlation between degree of continement of tire models and effectiveness of extinguishment. The relation of the agent to the flammable limits of the fuel, which for heptane range from 0.5 to $i$ percent, may well be another factor. Even with approximately equal fucl-consumption lates. the three fires, VIII, IX and X. were not necessurily burning at the same tuel oxygen latio. It is pussible that in fire $\mathbb{X}$ the configmation is such that air diflusion is restricted, esperoblly as compand


fuel mixture was considerably richer than in ot her fires. On the basis of llamminbility limit tests, it has been sugerested that the rolume of rapmizing liquids (and perlapps other acents) repuired for such at the is much lese than thate for times having 
a lean mixture caused by an excess of available air. ${ }^{2}$

In conducting the tests, it was found that optimum methods of attack varied with the fire model and particularly with the extinguishers. Generally, carbon tetrachloride was best employed by spraying on a hot surface to secure maximum vaporization, and in such manner as to cover the area with the decomposition products. Dry chemical extinguishers were most effective when operated to cover the whole flaming area at once. Carbon dioxide types seemed to work best when the agent was discharged in a sweeping motion near the fuel surface. Foam was effective only if it could be flowed onto the burning-liquid surface; its use was difficult in the presence of obstructions. To secure results that would be impartial and unprejudiced, the operators in every case endeavored to use an extinguisher to its maximum effectiveness. That this generally occurred is borne out by the fact that after increases from the first to third series, attributable to a learning effect, the number of successes in the last three series of tests remained approximately constant.

An inspection of the data of table 4 suggests that fire II is not representative of the same class of hazard as the other nine fires. It will be noted that fire VIII has about the same low number of successes, but it nevertheless ranks the extinguishers in essentially the same order as the remaining fires. A discordant ranking is given by fire II, and for this reason further analysis has been carried out omitting this fire. This anomalous behavior is confirmed by a statistical analysis on the data of table 4.

Omitting fire II, the other nine fires can be ranked in order of severity (most difficult to extinguish has rank 1) as follows:

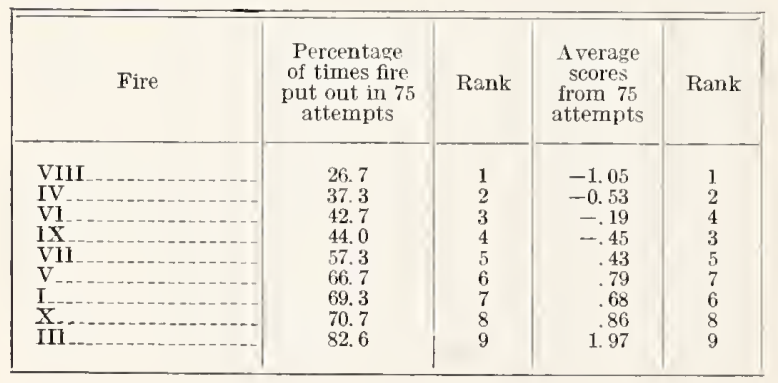

While it would be convenient to have a measure on a continuous scale, such as the area of a given type fire that could be put out, it is considered that adequate screening of the effectiveness obtainable with the extinguishers can be achieved by use of several fires selected from those employed in this program. From the results, it can be seen that when fire III is not extinguished, the performance

2E. H. Coleman and G. W. Stark, A Comparison of the extinguishing efficiency of bromochloromethane and carbon tetrachlolide, Chemistry \& Industry, p. 563 (1955). is certainly weak in relation to the over-all performance available with the extinguishers used in this test. If trials are successful on fire III, performance could be further tested on an intermediate fire, such as VII, and a difficult one, fire VIII.

For practical purposes, a standard of performance would have to be set. It is suggested that extinguishment could be defined, for example, as success in putting out a particular test fire 4 times in 5 trials, and further, to achieve an average score as described herein of approximately +1 or greater. It should be remembered, however, that even fire VIII, the most difficult test, does in no manner encompass the limit of possible hazards, but rather defines the limit of extinguishing capacity obtainable with devices of a size and type considered in this program.

Although the fire-test program was conducted outdoors under a wide variety of ambient conditions, the results based on scoring did not show an appreciable influence of any individual measured ambient factor, with the exception of wind speed. What appears to be a significant day-to-day variation for some fires is actually almost entirely due to the increase in scores from the first to the subseqnent series.

Analysis of the data indicates that wind speed, as a single variable, showed some statistically significant effect on the scores of only a few types of fires. The degree of wind sensitivity depended more on fire type than on type of extinguisher. Scores obtained on fires II, IV, and VI were adversely affected by increase in wind velocity, whereas scores on fire VII seemed to be favorably influenced by this condition. The rest of the fire models showed no significant trend in the scoring. The great number of cases of scores remaining unchanged by the effects of ambient conditions is considered to indicate the relative reproducibility of the scoring system used.

As had been expected, a high rate of discharge in any particular type of extinguisher seemed to enhance the effectiveness of the performance. This is shown in an examination of the results of tests with hand-pump and stored-pressure-type carbon tetrachloride devices, and also the 5-1b dry chemical extinguisher as against the two 4-lb models.

Using the 15 extinguishers tested, trials with only three, the 10-lb carbon dioxide and the two 4Ib dry chemical devices, met the suggested requirements mentioned earlier for the most severe fire, No. VIII. Trials with the 1-qt chlorobromomethane extinguisher narrowly missed the suggested performance on this fire, but because of high effectiveness when used on the other fires, this device stands with the other three extinguishers in a group with which the highest percentage of success for the whole program was attained. The 5lb dry chemical, 5-lb carbon dioxide, and 11/2- and 2 -qt stored-pressure carbon tetrachloride extinguishers gave suitable results when used on an intermediate fire such as No. VII. The suggested 
minimum requirements would be obtained on fire III with the $11 / 4^{-}$gal foam extinguisher, the $21 / 2^{-}$ lb carbon dioxide, the 1-qt stored-pressure carbon tetrachloride and one of the $11 / 2$-qt hand-pump carbon tetrachloride devices. The two 1-qt and the remaining $11 / 2-q t$ vaporizing-liquid hand pumps were unsuited for use on even this minimum fire, although it has been long considered a standard test for evaluating small extinguishers of this type. The results with these last extinguishers hare been corroborated by other investigators. ${ }^{3}$

In considering ease of handling of the several types with which the most successful operation was attained and the possibility of their successful use by a novice, it is necessary to remark that the 10lb carbon dioxide extinguisher, while effective, has a charge weight $21 / 2$ times that of other devices in its effectiveness group, and a total weight in excess of 3 times that of the next heaviest. This extinguisher also has a relatively short discharge range, forcing a close approach to the fire for effective use. The stored-pressure chlorobromomethane device may be operated at a considerable distance (up to $20 \mathrm{ft}$ ) from a fire. The dry chemical extinguishers are, howerer, the type most likely to lend themselves to effectire use as their moderate-to-good range and high accomplishment for their size are further augmented by the shielding effect that the powder affords against radiant heat.

3 T. B. Edwards, Armj Fire Extinguishment Research Program for Field Operation, Proc. Symposium on Fire Extinguishment Research and Engineering (U. S. Naval Civil Engineering Research and Evaluation Laborators, Port Hueneme, Calif., Norember 1954).

Whashington, Norember 16, 1956.

\section{Conclusions}

The following conclusions seem justified on the basis of the results of the test and the observations made thereon:

The test fires used for the study presented a useful scale for evaluation of extinguishing performance. From these, a group of three fires can be selected to provide a qualitative means for measuring the performance obtainable with other devices intended for use on flammable-liquid fires, especially those in hydrocarbon fuels.

The rather large variations in ambient conditions observed during the test did not affect extinguishing performance enough to cause statistically significant differences to appear in the results for most fire types.

Erratic results obtained with some of the extinguishers on certain fires could be ascribed to particular sensitivity of the extinguisher, perhaps related to an unmeasured variable, to the conditions of the fire test, and to the technique of the operator.

The apparent differences previously noted in the effectiveness obtainable with rarious types and sizes of extinguishers, all of which have sometimes been equally rated for use on small flammableliquid fires, have been generally substantiated by the results of the tests conducted in this program.

Extinguishers of the type of the 1-qt chlorobromomethane, 10-1b carbon dioxide, and 4-lb dry chemical devices described herein ranked rery closely with each other as useful derices for attack on the test fires, and were superior to the other types of extinguishers used in this program on flammable-liquid fires of limited extent. 


\section{BUILDING MATERIALS AND S'TRUC'TURES REPOR'TS}

[Continued from cover page II]

BMS37

BMIS38

BMIS39

BIIS40

BMIS41

BMS42

BIIS43

BMS44

BIIS45

BMS46

B.IS47

BMS48

BMS49

BMS50

BMS51

B.IS52

BMIS53

BMS54

B.IS55

B.IS56

BMS57

BMS58

BMS59

B.IS60

BMS61

B.IS62

BMS63

BMS64

B.IS 65

BMS66

B.IS67

B.MS68

B ITS69

BMS70

BMS71

BMS72

BMS73

BMS74

BMS75

BMS76

BMS77

BMIS78

BMS79

BIIS80

BMIS81

BMS82

BMS83

BMIS84

B MIS 85

BMS86

BMS87
Structural Properties of "Palisade Homes" Constructions for Walls, Partitions, and Floors Sponsored by Palisade Homes.

Structural Properties of Two "Dunstone" Wall Constructions Sponsored by the W. E. Dunn Manufacturing Co

Structural Properties of a Wall Construction of "Pfeifer Units" Sponsored by the Visconsin Units Co

Structural Properties of a Wall Construction of "Knap Concrete Wall Units" Sponsored by Knap America, Inc.

Effect of Heating and Cooling on the Permeability of Masonry Walls

Structural Properties of Wood-Frame Wall and Partition Construction with "Celotex" Insulating Boards Sponsored by The Celotex Corporation -

Performance Test of Floor Coverings for Use in Low-Cost Housing: Part 2

Surface Treatment of Steel Prior to Painting

Air Infiltration Through Windows

Structural Properties of "Scott-Bilt" Prefabricated Sheet-Steel Construction for Walls, Floors, and Roofs Sponsored by The Globe-Wernicke Co

Structural Properties of Prefabricated Wood-Frame Constructions for Walls, Partitions, and Floors Sponsored by American Houses, Inc

Structural Properties of "Precision-Built" Frame Wall and Partition Constructions Sponsored by the Homasote $\mathrm{Co}_{-}$

Metallic Roofing for Low-Cost House Construction.

Stability of Fiber Building Boards as Determined by Accelerated Aging- -

Structural Properties of "Tilecrete Type A" Floor Construction Sponsored by the Tilecrete Co

Effect of Ceiling Insulation Upon Summer Comfort

Structural Properties of a Masonry Wall Construction of "Munlock Dry Wall Brick" Sponsored by the Munlock Engineering Co

Effect of Soot on the Rating of an Oil-Fired Heating Boiler

Effects of Wetting and Drying on the Permeability of Masonry Walls

A Survey of Humidities in Residences

Roofing in the United States-Results of a Questionnaire

Strength of Soft-Soldered Joints in Copper Tubing

Properties of Adhesives for Floor Coverings.

Strength, Absorption, and Resistance to Laboratory Freezing and Thawing of Building Bricks Produced in the United States

Structural Properties of Two Nonreinforced Monolithic Concrete Wall Constructions -

Structural Properties of a Precast Joist Concrete Floor Construction Sponsored by the Portland Cement Association.

Moisture Condensation in Building Walls

Solar Heating of Various Surfaces

Methods of Estimating Loads in Plumbing Systems

Plumbing Manual

Structural Properties of "Mu-Steel" Prefabricated Sheet-Steel Constructions for Walls, Partitions, Floors, and Roofs, Sponsored by Herman A. Mugler

Performance Test for Floor Coverings for Use in Low-Cost Housing: Part 3

Stability of Fiber Sheathing Boards as Determined by Accelerated Aging-........

Asphalt-Prepared Roll Roofings and Shingles . . . .

Fire Tests of Wood- and Metal-Framed Partitions struction Sponsored by the Homasote $\mathrm{Co}_{-}$

Indentation Characteristics of Floor Coverings "U. S. S. Panelbilt" Prefabricated SheetSteel Constructions for Walls, Partitions, and Roofs Sponsored by the Tennessec Coal, Iron \& Railroad Co

Survey of Roofing Materials in the North Central States

Effect of Outdoor Exposure on the Water Permeability of Masonry Walls

Properties and Performance of Fiber Tile Boards.

Structural, Heat-Transfer, and Water-Permeability Properties of Five Earth-IIall Constructions.

Water-Distributing Systems for Buildings

Performance Test of Floor Coverings for Use in Low-Cost Housing: Part 4

Field Inspectors' Check List for Building Constructions (cloth cover $5 \times 7 \frac{1}{2}$ inches) --

Water Permeability of Walls Built of Masonry Units

Strength of Sleeve Joints in Copper Tubing Made With Various Lead-Base solders.

Survey of Roofing Materials in the South Central States.

Dimensional Changes of Floor Coverings With Changes in Relative II umidity and Temperature

Structural, Heat-Transfer, and Water-Permeability Properties of "Speedbrik" Construction Sponsored by the General Shale Products Corporation

A Method for Developing Specifications for Building Construction-Report of Sulcommittee on Specifications of the Central Housing Committee on Rescarch, Design, and Construction. 


\section{BUILDING MATERIALS AND STRUCTURES REPORTS}

\section{[Continued from cover page Irr]}

BMS88 Recommended Building Code Requirements for New Dwelling Construction With BMS89 Special Reference to War Housing Wood-Frame Wall Construction Sponsored by the Homasote Co.

BMS90

BMS91

BMS92

BMS93

BMS94

BMS95

BMS96

BMS97

BMS98

BMS99

BMS100

BMS101

BMS102

BMS103

BMS104

BMS105

BMS106

BMS107

BMS108

BMS109

BMS110

BMS111

BMS112

BMS113

BMS114

BMS115

BMS116

BMS117

BMS118

BMS119

BMS120

BMS121

BMS122

BMS123

BMS124

BMS125

BMS126

BMS127

BMS128

BMS129

BMS130

BMS131

BMS132

BMS133

BMS134

BMS135

BMS136

BMS137

BMS138

BMS139

BMS140

BMS141

BMS142

BMS143

BMS144

BMS145

BMS146

BMS147

BMS148

BMS149

BMS150 Floors, and Roofs Sponsored by the PHC Housing Corporation A Glossary of Housing Terms Fire-Resistance Classifications of Building Constructions Water Permeability and Weathering Resistance of Stucco-Faced, Gunite-Faced, and "Knap Concrete-Unit" Walls Tests of Cement-Water Paints and Other Waterproofings for Unit-Masonry Walls
Properties of a Porous Concrete of Cement and Uniform-Sized Gravel Properties of a Porous Concrete of Cement and Uniform-Sized Gravel

Physical Properties of Terrazzo Aggregates - "Multiple Box-Girder Plywood Panels" for Walls, Floors, and Roofs

Relative Slipperiness of Floor and Deck Surfaces

Strength and Resistance to Corrosion of Ties for Cavity Walls

Painting Steel_.

Measurements of Heat Losses From Slab Floors Partitions, Floors, and Roofs Sponsored by the Douglas Fir Plywood Association.

Paint Manual with particular reference to Federal Specifications

Laboratory Observations of Condensation in Wall Specimens

Building Code Requirements for New Dwelling Construction

Temperature Distribution in a Test Bungalow With Various Heating Devices....

Strength of Houses: Application of Engineering Principles to Structural Design

Paints for Exterior Masonry Walls

Performance of a Coal-Fired Boiler Converted to Oil
Properties of Some Lightweight-Aggregate Concretes With and Without an AirEntraining Admixture.

Fire Resistance of Structural Clay Tile Partitions

A Study of a Baseboard Convector Heating System in a Test Bungalow

Preparation and Revision of Building Codes

Fire Resistance of Walls of Lightweight Aggregate Concrete Masonry Units

Stack Venting of Plumbing Fixtures

Wet Venting of Plumbing Fixtures

Fire Resistance of Walls of Gravel-Aggregate Concrete Masonry Units.

Investigation of Failures of White-Coat Plasters

Physical Properties of Some Samples of Asbestos-Cement Siding

Fire Tests of Wood-Framed Walls and Partitions With Asbestos-Cement Facings.

Fire Tests of Steel Columns Protected With Siliceous Aggregate Concrete.........

Stone Exposure Test Wall

The Self-Siphonage of Fixture Traps

Effect of Aging on the Soundness of Regularly Hydrated Dolomitic Lime Putties....

Atmospheric Exposure Tests of Nailed Sheet Metal Building Materials

Fire Endurance of Shutters for Moving-Stairway Openings

Methods and Equipment for Testing Printed-Enamel Felt-Base Floor Covering
Fire Tests of Gunite Slabs and Partitions

Capacities of Plumbing Stacks in BuildingS.

Live Loads on Floors in Buildings

Fire Resistance of Concrete Floors

Fire Tests of Steel Columns Encased With Gypsum Lath and Plaster.

Properties of Cavity Walls

Influence of the Wash From Bronze on the Weathering of Marble Floors.

Studies of Stone-Setting Mortars

Second Edition, Selected Bibliography on Building Construction and Maintenance..-

Fire Endurance of Open-Web Steel Joist Floors With Concrete Slabs and Gypsum Ceilings

Frost Closure of Roof Vents.

Fire Tests of Brick Walls

Sound Insulation of Wall, and Floor Constructions

Supplement to BMS144, Sound Insulation of Wall, Floor, and Door Constructions..Fire Effects and Fire Control in Nitrocellulose Photographic-Film Storage....... Plasticity and Water Rententivity of Hydrated Limes for Structural Purposes Effects of Mineral Additives on the Durability of Coating-Grade Roofing Asphalts_--Fifteen-Year Exposure Test of Porcelain Enamels Combustible Contents in Buildings_... Methods of Testing Small Fire Extinguishers

* Out of print. 